\title{
KIRKLARELİ HAPISHANESI
}

\author{
Kırklareli Prison
}

\section{Gülay APA KURTişOĞLU*}

ÖZ: 1858 Ceza Kanunu'yla hapis cezası asli bir ceza olarak Osmanlı Hukuku'nda yer almaya başlayınca, asli bir ceza infaz kurumu olarak da hapishaneler inşa edilmeye başlanmıştır. Osmanlı Dönemi'nde modern anlamdaki hapishanelerin yapılanması, Tanzimat ve Sultan II. Abdülhamit dönemlerine rastlar. Sultan II. Abdülhamit döneminde ülkenin pek çok yerinde kâgir, tek veya iki katlı, eski binalardan dönüştürülen veya şahıslardan kiralanan hapishaneler yaygınlaşmaya başlamıştır. Bu dönemde inşa edilen Kırklareli Hapishanesi de bunlardan biridir. Kırklareli'de 1867 yılında bir hapishane inşaatına başlanmış ancak bu hapishane, 1888 y1lında ihtiyaca cevap veremez hale gelmiştir. Zamanla tamir edilse de yeterli gelmemiş, Hasip Paşa'nın mutasarrıflığı döneminde Hükümet Konağı ve Jandarma Dairesiyle birlikte hapishane yeniden inşa edilerek 1892 yılında tamamlanmıştır. Zamanla eklemelerle özgün planı değişen Kırklareli Hapishanesi, dönemin hapishane binalarıyla benzer özellikleri ve plan şemasıyla önemli bir kamu yapısıdır. Daha önce mimari açıdan incelenmeyen Kırklareli Hapishanesi detaylı olarak ele alınmıştır.

Anahtar Kelimeler: Kırklareli, Osmanlı Dönemi, kamu yapısı, hapis, hapishane

ABSTRACT: With the 1858 Criminal Code, when the prison sentence began to be included in the Ottoman Law as a basic penalty, prisons started to be built as a primary penal institution. Structuring of modern prisons in the Ottoman Period, Tanzimat and Sultan II. It coincides with the times of Abdülhamit. Sultan II. During the reign of Abdülhamit, prisons of masonry, one or two floors, converted from old buildings or rented from individuals, started to spread in many parts of the country. Kirklareli Prison, which was built during this period, is one of them. Construction of a prison was started in 1867 in Kurklareli, but this prison became unable to meet the needs in 1888. Although it was repaired in time, it was not sufficient, and the prison was rebuilt together with the Government House and Gendarmerie Office during the governor of Hasip Pasha and was completed in 1892. Kurklareli Prison, whose original plan changed with additions over time, is an important public building with similar features and plan scheme with the prison buildings of the period. Kirklareli Prison, which has not been studied architecturally before, has been discussed in detail.

Keywords: Kırklareli, Ottoman Period, public structure, jail, prison

\footnotetext{
* Doç. Dr., Trakya Üniversitesi, Edebiyat Fakültesi, Sanat Tarihi Bölümü, Balkan Yerleşkesi, Edirne, gulayapa@trakya.edu.tr; ORCID: 0000-0003-4504-5993

Geliş Tarihi / Received: 11.03.2021

Kabul Tarihi / Accepted: 03.04.2021

Yayın Tarihi / Published: 30.07.2021
} 


\section{Giriş}

Hapis kelimesi, "bir yere kapatıp salıvermeme" ya da "yasalara göre suçu belirlenen kimseyi cezaevine koyma cezası" anlamına gelmektedir (Sozluk.gov.tr, erişim tarihi: 21.07.2020).

Hapishane ise hapsolunan yer, cezaevi ve mahkûmların cezalarını çekmek üzere kaldıkları yer anlamına gelir (Develioğlu, 1996:394). Cezası henüz kesinleşmemiş kişilerin kaldıkları mekâna ise mahbes denilmektedir. Bu sebeple mahbes ve hapishane kelimesi birbirinden ayrılmaktadır.

Müessese olarak hapishane suça yönelik cezaların uygulanmasındaki değişime bağlı olarak daha sonra ortaya çıkmıştır. İnsanlığın var oluşundan beri suç olgusunun varllğ 1 kabul edilmesine rağmen, suça verilen cezalarda hapis uygulamaları modern hukukun hapis cezalarından farklıdır. Bu yüzden "hapishane" müessesini modern hukukun içerisinde değerlendirmek gerekir. Hapis cezalarının farklı dönemlerde uygulamaları konusunda yapılmış çeşitli çalışmalar mevcuttur. Ancak araştırmamızın kapsamı dışında olduğu için bu konuya değinilmeyecektir. ${ }^{1}$

Hapishanenin cezaevi olarak mekânsal kullanımının ne zaman başladığı kesin değildir. 1596 yılında açılan Amsterdam Hapishanesi ilk hapishane olarak kabul edilmektedir (Demirkol, 2012:12). Konumuz Osmanlı Dönemi içinde yer aldığı için, bu dönemde hapishanenin başlangıcına kısaca değinmekte fayda vardır. Osmanlı Klasik Dönemde İslam Hukuku uygulaniyordu. ${ }^{2}$

${ }^{1}$ Konu hakkında bk. Michel Foucoult, Hapishane'nin Doğuşu, Çev. Mehmet Ali Kılıçbay, Ankara, 1992.

${ }^{2}$ Osmanlı hukukunda suç ve cezalar konusunda bk. Ali Bardakoğlu, "Ceza”, Türkiye Diyanet Vakfi İslam Ansiklopedisi, C:VII, İstanbul, 1997, s. 470-478; Mehmet Akif Aydın, "Osmanl1 Ceza Hukuku", Türkiye Diyanet Vakf İslam Ansiklopedisi, C: VII, İstanbul, 1997, s. 478482; Mustafa Avcı, Osmanlı Hukukunda Suçlar ve Cezalar, İstanbul, 2004; Mustafa Şentop, Tanzimat Dönemi Osmanl Ceza Hukuku: Kanunlar, Tadiller, Layihalar, Uygulama, Yaylacık Matbaası, İstanbul, 2004; Mehmet Koç, Osmanlı Hukukunda Ta'zir Suç ve Cezaları, Doktora Tezi, NEÜ Sosyal Bilimler Enstitüsü, Konya, 2017. 
Dolayısıla hapsetme ve hapis cezas1 konusunda İslam Hukuku'nun cezaya bakış açısı geçerliydi. ${ }^{3}$ Osmanlı Hukuku'nda ta'zir (Koç, 2017:16) ${ }^{4}$ ve kanunname hükümleri hapis cezasının kaynağını oluşturmuştur (Yıldıztaş, 1997:41; Demirkol, 2012: 20). Osmanlı ceza hukuku sadece şer'i veya örfi ceza hukukunu değil bu ikisinin bütününü kapsar (Aydın, 1997: 478).

Şer'i hukukta, hapis cezası olmadığı için modern anlamda hapishanelerden bahsedilemez. Ancak, ta'zir'en cezalandırılan suçlardan ötürü, padişah ve onun adına bu yetkiyi kullananlar tarafından hapis cezaları verilmiştir.

Ancak Osmanlı Devleti'nde klasik dönem hapis cezaları, genellikle bir ceza olarak değil de insanın hüküm giyip cezasının belirlendiği zamana kadarki bir tutulma işlemidir.

Osmanlı'da modern anlamda hapishanelerin inşa edildiği döneme kadar, mahpeslere karanlık, nemli ve havasız olmasından dolayı Farsça'da; karanlık sıkıntı ve dehşete düşürücü yer anlamına gelen "zindan" adı verilmiştir (Çiçen, 2010:17).

Bir nevi hapis: sürgün karışımı olan hapis cezasının etkin bir yöntem olarak benimsenmesi ve ceza infaz kanununda önemli bir yer işgal etmesi Tanzimat'la başlayan bir süreçtir (Bardakoğlu, 1997:63).

Osmanlı'da ceza hukukunda gerçekleşen reformlar salt Batı'nın taklitçi tezahürü değil, dünya siyasetinin ana gündem maddeleri olan modernleşme ve merkezileşmeye paralel olarak ortaya çıkmıştır (Akın, 2011:24).

“Osmanlı Devleti’nde hapis cezası asli bir ceza değil tali bir ceza idi. Hâkimin takdirine bırakılan hapis cezasının süresinin alt ve üst sınırları net olarak belli değildi. Tanzimat dönemi ceza kanunlarıyla $(1840,1851,1858)$ birlikte hapis cezas Osmanlı kanunlarında, alt ve üst sınırlarıyla birlikte süresi belirli, etkin bir ceza olarak yer almaya başlamıştır. Özellikle 1858 Ceza Kanunu'yla hapis cezası, asli bir ceza olarak başrolü üstlenmiştir. Hapsetmek asli bir ceza olarak Osmanlı

\footnotetext{
3 İslam hukukunun cezaya bakış açısı için bk. İlhan Akbulut, "İslam Hukukunda Suç ve Cezalar”, Ankara Üniversitesi Hukuk Fakültesi Dergisi, Cilt 52, Sayı 1, Ankara, 2003, s. 167181; Rudolf, Peters, Crime and Punishment in Islamic Law, Cambridge, 2005; Timur Demirbaş, "Hürriyeti Bağlayıcı Cezaların ve Cezaevlerinin Evrimi", Hapishane Kitabı, İstanbul, 2010, s. 28-34; Mehmet Emin Artuk ve Mehmet Emin Alşahin, "Hapis Cezalarının ve Cezaevlerinin Tarihi Gelişimi”, Marmara Üniversitesi Hukuk Araştırmaları Dergisi Özel Sayı Mehmet Akif Aydın'a Armağan, İstanbul, 2015, s. 145-185; Mehmet Zeki Uyanık, İslam Hukukunda Hapis Cezası ve Hapishane, Hikmetevi Yayınları, İstanbul, 2017.

${ }^{4}$ Ta'zîr suçları, şâri tarafından hakkında belirlenmiş bir ceza müeyyidesi olmayan, had ve kısas suçları dışında kalan, miktarı ve uygulaması yasama organına veya belli ölçüler dâhilinde takdiri hâkime bırakılmış Allah veya kul hakkını ihlal eden hukuka aykırı fiillere denir.
} 
Hukuku'nda yerini alırken artık hapishane de asli bir ceza infaz kurumu olarak Osmanlı Devleti'nde önemli bir yer tutacaktır" (Demirkol, 2012: 21).

$\mathrm{Bu}$ durum aynı zamanda Osmanlı Devleti için mahbesten hapishaneye geçiş demekti (Öztürk, 2014). ${ }^{5}$ Bu süreçte Osmanlı topraklarında da pek çok yerde hapishane binalarının inşa edilmeye başlandığı görülmektedir.

Osmanlı Dönemi'nde modern anlamdaki hapishanelerin yapılanması, Tanzimat ve Sultan II. Abdülhamit dönemlerine rastlar. ${ }^{6}$ Sultan II. Abdülhamit döneminde ülkenin pek çok yerinde kâgir, tek veya iki katlı, eski binalardan dönüştürülen veya şahıslardan kiralanan genellikle bodrum katlardan oluşan hapishaneler yaygınlaşmaya başlamıştır (Temel, 2009:112).

II. Meşrutiyet dönemi ise dönem içinde üç ayrı evreye ayırabileceğimiz Osmanlı Devleti'nde hapishane 1slahatının başladığı ve dönem boyunca devam ettiği yıllardır. Bu ıslahat çabaları çok kapsamlı verilerin dönemin şart ve ihtiyaçlarına göre değişik bakış açılarıyla toplandığ 1 dönemlerdir (Demirkol, 2015: 989).

Osmanlı Dönemi Hapishanelerini mimari açıdan ele alan çalışmalar sinırlıdır. Bugüne kadar Hapishane binalarının tam olarak tipolojisi de yapılmış değildir. Tipolojiye yönelik "1şınsal planlı" hapishanelere yönelik bir tez çalışması bulunmaktadır (Sezer, 2019). Osmanlı Hapishane binalarıyla ilgili çalışmalar çoğunlukla arşiv belgelerine dayanan ve yapının tarihi

\footnotetext{
${ }^{5}$ Osmanlı Döneminde hapishaneye geçiş süreci için bk. Sevcan Öztürk, XIX. Yüzyll Osmanlı Ceza Sisteminde Dönüşüm: Zindandan Hapishaneye Geçiş, Yüksek Lisans Tezi, Adnan Menderes Üniversitesi Sosyal Bilimler Enstitüsü, Aydın, 2014.

6 Konu hakkında detaylı bilgi için bk. Gizem Parlakoğlu, II. Abdülhamit Dönemi Hapishanelerinin Genel Özellikleri ve Uygulamaları, Yüksek Lisans Tezi, Mardin Artuklu Üniversitesi Sosyal Bilimler Enstitüsü, Mardin, 2018.
} 
sürecini ele alan makale ${ }^{7}$ ve tezlerden ${ }^{8}$ oluşmaktadır Hapishaneleri mimari açıdan detaylı olarak ele alan çalışmalar oldukça azdır. ${ }^{9}$ Alev Kuru

\footnotetext{
${ }^{7}$ Osmanlı Dönemi'nde hapishanelerle ilgili makaleler için bk. Kemal Daşcıoğlu, “Osmanlı Arşiv Belgelerine Göre Bodrum Kalesi ve Hapishanesi”, SDÜ Fen Edebiyat Fakültesi Sosyal Bilimler Dergisi Prof. Dr. Bayram Kodaman'a Armağan Özel Sayısı, Samsun, 1993, s. 212 225; Tekin, Saadet, "XX. Yüzyılın Başlarında Aydın Vilayeti ve Mülhakatındaki Hapishanelerin Genel Durumu”, Celal Bayar Üniversitesi Sosyal Bilimler Dergisi, Cilt: 4, Sayı: 2, Manisa, 2006, s. 65-77; Kemal Daşc1oğlu, "Osmanlı Arşiv Belgelerine Göre Bodrum Kalesi ve Hapishanesi", Süleyman Demirel Üniversitesi Fen-Edebiyat Fakültesi Sosyal Bilimler Dergisi, 2010, s. 212-225; Oya Şenyurt, "Proje ve Belgeleriyle 20. Yüzyıl Başında İzmit Hapishanesinin Tasarımı, Mimarlık Tarihi, 2010, Sayı: 352, s. 60-65; Zafer Atar, "20. Yüzyıl Başlarında Turgutlu Hapishanesinin Genel Durumu”, Celal Bayar Üniversitesi Sosyal Bilimler Dergisi, Cilt: 9, Sayı: 1, Manisa, 2011, s. 87-102; Jülide Akyüz Orat, Hapishane Islahatı Bağlamında Çerkes Hapishanesinin Modernleşme Çalışmaları, Folklor/Edebiyat, Cilt:17, Sayı: 66, 2011, s. 81-94; Jülide Akyüz Orat ve Fadimana Çelik, "Diyarbakır Vilayeti Hapishaneleri”, Sosyal Bilimler Enstitüsü Dergisi, Sayı: 7, 2011, s. 73-95; Ali Rıza Gönüllü, “Osmanlı Devleti'nin Son Döneminde Isparta Hapishanesi (1867-1920)", Selçuk Üniversitesi Türkiyat Araştırmaları Dergisi, Sayı: 29, Konya, 2011, s. 342-392; Nurgül Bozkurt, "XX. Yüzyıl Başlarında Kütahya Hapishanesinin Genel Durumu", Uluslararası Sosyal Araştırmalar Dergisi, Cilt: 5, Sayı: 2, 2012, s. 261-277; Ferudun Ata, "Osmanlı Döneminde Bozkır Hapishanesi”, Uluslararası Sempozyum: Geçmişten Günümüze Bozkır, Konya, 2016, s. 393-398; Halim Demiryürek, "Hüdavendigar Vilayetinde Hapishaneler ve Mahpuslar (1914-1917)", Uluslararası Sosyal Araştırmalar Dergisi, Cilt: 9, Sayı: 42, 2016, s. 552-562; Kurtuluş Demirkol, "Edirne Vilayeti Örneğinde Osmanlı Hapishanesi Çalışanları”, Balkan Araştırma Enstitüsü Dergisi, Cilt: 6, Sayı:1, 2017, s. 79-107; Eyyub Şimşek, "XX. Yüzyıl Başlarında Trabzon Hapishanesi (1900-1914)”, Karadeniz Incelemeleri Dergisi, Sayı: 23, 2017, s. 163-196; Serap Sunay, "Son Dönem Osmanlı Taşra Hapishanelerine Bir Örnek: Bolvadin Hapishanesi”, Afyon Kocatepe Üniversitesi Sosyal Bilimler Dergisi, Cilt: 20, Say1: 1, 2018, s. 43-66.

${ }^{8}$ Osmanlı Döneminde inşa edilen hapishanelerle ilgili tezler için bk. Ufuk Adak, XIX. Yüzyılın Sonları XX. Yüzyılın Başlarında Aydın Vilayeti'ndeki Hapishaneler, Yüksek Lisans Tezi, Ege Üniversitesi Sosyal Bilimler Enstitüsü, İzmir, 2006; Kurtuluş Demirkol, II. Meşrutiyet Döneminde Edirne Vilayeti Hapishaneleri, Doktora Tezi, Sakarya Üniversitesi Sosyal Bilimler Enstitüsü, Sakarya, 2012; Emel Demir, Osmanl Devletinde Hapishane Reformu, Çanakkale Hapishanesi Örneği, Yüksek Lisans Tezi, Çanakkale Onsekiz Mart Üniversitesi Sosyal Bilimler Enstitüsü, Çanakkale, 2013; Nazmiye Akbey, XIX. Yüzyılın Sonları XX. Yüzyılın Başlarında Sinop Hapishanesi, Yüksek Lisans Tezi, Celal Bayar Üniversitesi Sosyal Bilimler Enstitüsü, Manisa, 2015; Banu Yılmaz, Osmanl Dönemi Bursa Hapishanesi, Yüksek Lisans Tezi, Uşak Üniversitesi Sosyal Bilimler Enstitüsü, Uşak, 2015; Beyza Karakaya, Musul Vilayeti Hapishaneleri (1864-1918), Yüksek Lisans Tezi, Marmara Üniversitesi Türkiyat Araştırmaları Enstitüsü, Türk Tarihi Anabilim Dalı, İstanbul, 2016; Özlem Akpınar, Meşrutiyetten Cumhuriyete Konya Hapishaneleri (1876-1922), Yüksek Lisans Tezi, Selçuk Üniversitesi Sosyal Bilimler Enstitüsü, Konya 2017; Gizem Parlakoğlu, II. Abdülhamit Dönemi Hapishanelerinin Genel Özellikleri ve Uygulamalarl, Yüksek Lisans Tezi, Mardin Artuklu Üniversitesi Sosyal Bilimler Enstitüsü, Mardin, 2018; Ayşegül Yaşar,
} 
Çakmakoğlu'nun Sinop Hapishanesi hakkındaki kitabı bu konudaki önemli çalışmalardandır. ${ }^{10}$

Araştırmamızın konusu Kırklareli il merkezinde yer alan Hapishane binasıdır. Bu çalışmadaki amacımız 1867 yılında inşa edilen Kırklareli Hapishanesi'ni mimari özellikleri ile detaylı bir şekilde ele almaktır.

\section{Kırklareli Hapishanesi \\ 1.1.Tarihçesi}

Sancak merkezi olan Kırkkilise, uzun yıllar nahiye olarak yönetilmiştir. Sultan Abdülmecit döneminde kaza olan Kırkkilise, 1877-1878 Osmanl1-Rus Harbi'ne kadar kaza olarak kalmıştır. 1877-1878 Osmanlı:Rus Savaşı'nda işgale uğrayan Kırkkilise'yi Ruslar, 1879 yılının Şubat-Mart aylarında tahliye etmişler ve şehir 1879 senesi Nisan ortalarında geri alınmıştır. Şehir, yapılan idari düzenlemeyle 1879 yılının Mart ayı ortalarında birinci sınıf mutasarrıflık haline getirilmiştir (Dursunkaya, 1948: 136:138).

Kırkkilise'de 1867 yılında bir hapishane (Şen, 2007:28) inşaatına başlanmış ancak bu hapishane yetersiz kalmıştır. 1888 yılında ihtiyaca cevap veremez hale gelmiştir. Hapishane ve hapishanenin içinde hastane olarak kullanılan oda oldukça dar ve gayri sıhhi bir haldedir. Sancağın yeni bir hapishaneye ihtiyacı vardır. Fakat yine ekonomik sebeplerden dolayı Dâhiliye Nezareti yeni bir hapishanenin inşasına izin vermemiş, bunun yerine eski hapishanenin tamiratı zaruret halini almış mahallerinin tamiratı yoluna gidilmesini seçmiştir. İzin verilen tamirat için keşif yapılması, yapılan keşfin sonucunda usulüne ve nizamnameye uygun olarak hazırlanan keşif defterinin gönderilmesi istenmiştir (BOA. DH.MKT. 1506/115). Tamirin hapishaneyi kurtarmaya yetmeyeceği düşünülmüş olmalı ki; daha sonra tamirat için değil

Osmanl Devletinin Son Dönemlerinde Antalya Hapishanesi, Yüksek Lisans Tezi, Kütahya Dumlupınar Üniversitesi Sosyal Bilimler Enstitüsü, Kütahya, 2019; Seval Yolaçan, Nevşehir Hapishanesi (1849-1920), Yüksek Lisans Tezi, Aksaray Üniversitesi Sosyal Bilimler Enstitüsü, Aksaray, 2019; Yahya Sülek, 19. Yüzyıl Sonu ve 20. Yüzyll Başlarında Teke Sancağı'nda Hapishaneler, Yüksek Lisans Tezi, Akdeniz Üniversitesi Sosyal Bilimler Enstitüsü, Antalya, 2019; Kibar İliş, II. Meşrutiyet Döneminde Bitlis Hapishaneleri, Yüksek Lisans Tezi, Bitlis Eren Üniversitesi Sosyal Bilimler Enstitüsü, Bitlis, 2019.

${ }^{9}$ Remzi Aydın, "Mühendis Mehmed Ali Bey'in Avanos'taki Projeleri”, İstem, Y1l: 16, Say1: 32, Konya, 2018, s. 357-383; Remzi Aydın, "Mimar Kemaleddin Bey'in Hapishane Projeleri”, Osmanlı Sanatında Değişim ve Dönüşüm, Konya, 2019, s. 11-36; Remzi Aydın, "Alman Mimar August Carl Friedrich Jasmund'un Yedikule'deki Hapishane Projesi”, Türkİslâm Medeniyeti Akademik Araştırmalar Dergisi, Cilt: 15, Sayı: 29, Konya, 2020, s. 9-28.

${ }^{10}$ Alev Çakmakoğlu Kuru, Sinop Hapishanesi, Atatürk Kültür Merkezi Başkanlığı Yayınları Ankara, 2004. 
yeni bir hapishanenin inşası için yazışmaların yapıldığını görüyoruz. Aynı yıl, inşa edilmesi planlanan hapishanenin keşif defteri ve resmi, fenni kurallara uygunluğunun tetkik edilmesi amaciyla ilgili dairelere gönderilmiş (BOA. DH.MKT. 1562/36) ve yine aynı yılın sonunda gönderilen resim ve keşif defterinin fenni kurallara uygun olmadığı anlaşılmıştır (BOA. DH.MKT. 1579/89). Yaklaşık altı ay sonra 1890 ortalarında hapishanenin inşasına harcanacak para belirlenmiştir. Masraf 51.689 kuruştur. Bu paranın yarısı vilayet bütçesinden ödenecek, diğer yarısı ise yardımseverlerin bağışıyla karşılanacaktır (BOA. DH.MKT. 1737/56). Fakat tahsis edilen bu meblağ yetmemiş, 1891 yılının sonunda 5.000 kuruşa daha ihtiyaç duyulmuştur (BOA. DH.MKT. 1875/35). Hasip Paşa'nın mutasarrıflı̆̆ döneminde Hükümet Konağı ve Jandarma Dairesiyle birlikte hapishanenin inşaatı 1892 yılında tamamlanmıştır (Demirkol, 2012:47).

Kırkkilise Hapishanesi, inşaatı 1892 yılında bitirilmiş olmasına rağmen, II. Meşrutiyet Dönemi'ne girildiği tarihlerde tamire muhtaç ve ihtiyaca cevap veremez hale gelmiştir (BOA. DH. TMIK.S 67/63). Geçici çözüm olarak tıpk1 Tekfurdağı sancağında yapıldığ gibi hapishaneye ek olarak başka bir bina kiralanması yoluna gidilmiştir (BOA. Y.A.RES. 151/61) (Demirkol, 2012:47).

\subsection{Yapının Konumu}

Eski Cezaevi binası Kırklareli ilinin Merkez ilçesinde bulunup Hapishane Sokak ile Dereüstü Sokağı'nın kesiştiği yerde bulunmaktadır (Şekil 1). Merkez ilçesinin önemli caddelerinden Mustafa Kemal Bulvarı'na oldukça yakındır. Arşiv belgelerinden hapishanenin ilk olarak 1867 yılında inşa edildiği, bu yapının harap olması sebebiyle de 1892 yılında, günümüzde mevcut olmayan Hükümet Konağı ve Jandarma Dairesi ile birlikte yeniden inşa edildiği anlaşılmaktadır. Günümüzde Jandarma Orduevi ile Adliye Sarayının arasında kalmaktadır. Bulunduğu konumu itibariyle de ilk inşasının hapishane binası olarak tasarlandığı anlaşılmaktadır. 


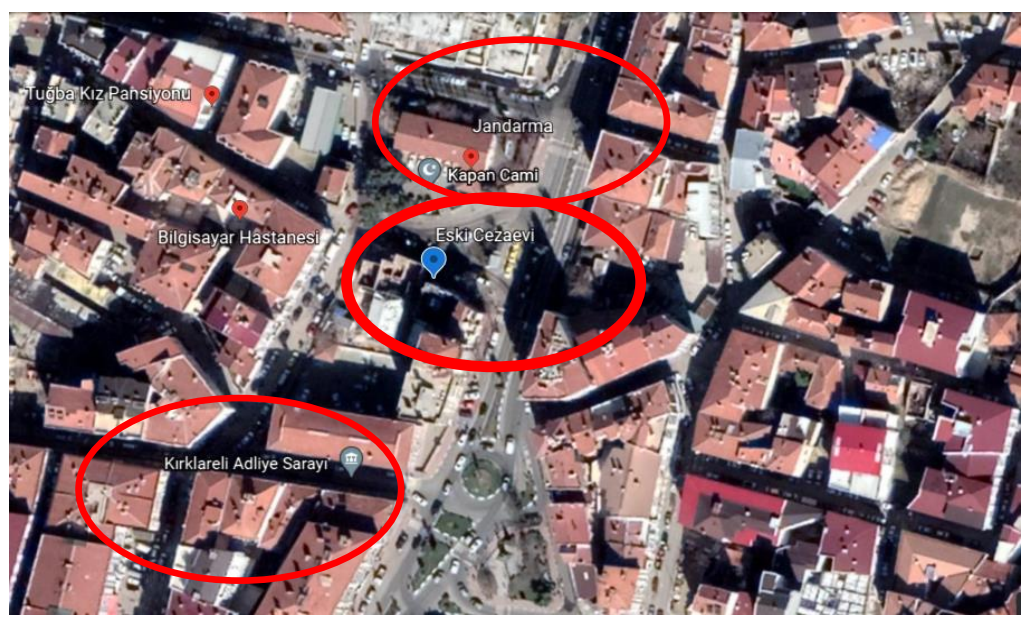

Şekil 1: Yapının bulunduğu konum (Google Earth 2020)

\subsection{Mimari Özellikleri}

Düzgün bir plan şeması göstermeyen yapı iki katlıdır (Resim 1). Alt katta moloz taş ve tuğladan almaşık duvar görülürken üst kat tamamen tuğladan inşa edilmiştir (Resim 2). Ara duvarlar ahşap bağdadi teknikte yapılmıştır (Resim 3). Alt kat pencere sövelerinde kesme taş, üst kat pencere sövelerinde ise tuğla kullanılmıştır. Pencereler ve ana girişler demir parmaklıklarla kapatılmıştır. Yapının kuzey bölümünde üst örtü ahşap, güney bölümünde ise betonarmedir. Yapının kuzey ve güney bölümünün farklılık göstermesi yapının geçirdiği tamiratlara ve yeniden inşa sürecine işaret etmektedir.

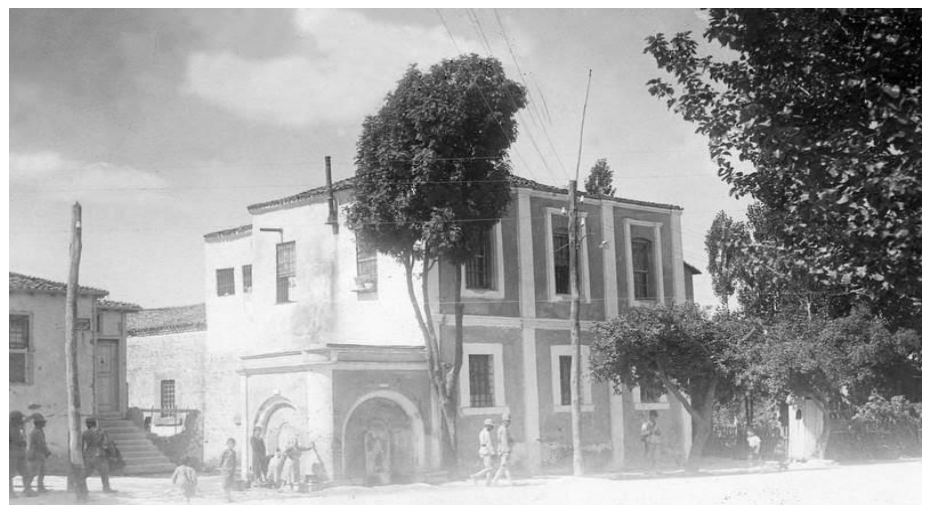

Resim 1: Genel görünüş 


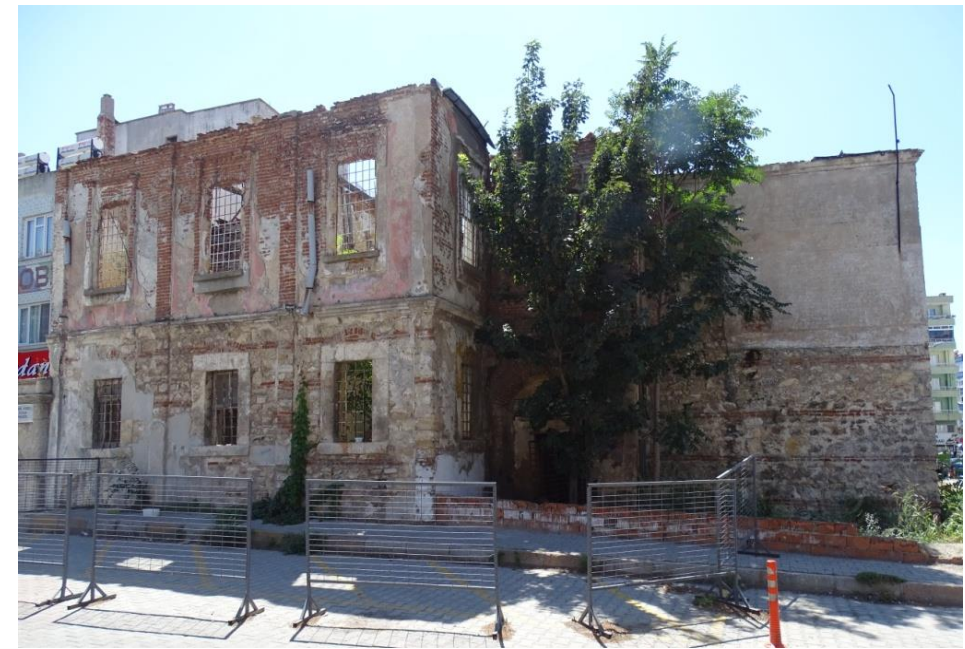

Resim 2: Kuzey cephe, genel görünüş

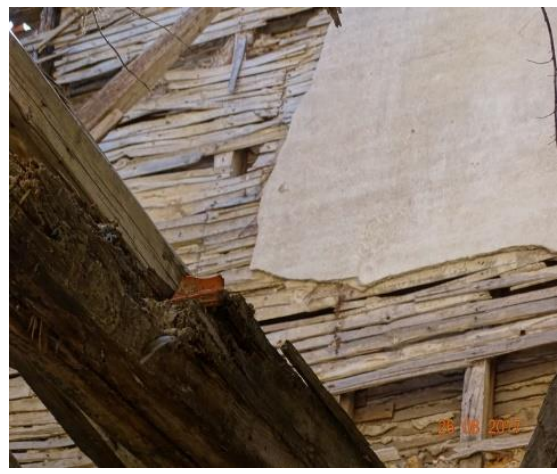

Resim 3: Bağdadi teknikte yapılmış ara duvarlar

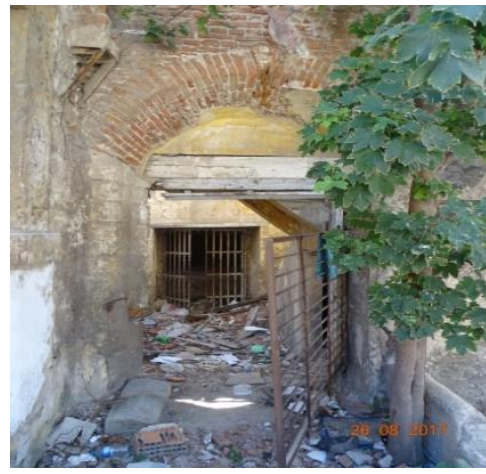

Resim 4: Yapının ana girişi

Yapıya kuzeybatı köşesindeki kapıdan girilmektedir (Resim 4). Profilli taş söve ile çevrelenen girişin kapı kanatları günümüzde mevcut değildir. Giriş açıklığını demir kafes örtmektedir ve ana girişten merdiven holüne geçilmektedir. Bu merdiven holünden bodrum kata ulaşılmaktadır. Burada yan yana sıralanan, zemin kazılarak oluşturulmuş üç adet hücre odası ve küçük bir hol mevcuttur (Resim 5). Tavan sıvanarak üzeri boyanmıştır. Zemin kat ile arasında bulunan döşeme muhdes betonarmedir. Hücrelerin kapıları demir 
parmaklıkla örtülmüştür. Kaynaklardan hücrelerin varlığıyla ilgili şu bilgilere ulaşılmaktadır;

“Dr. Pollitz 2 Nisan 1917 tarihinde Kırkkilise Hapishanesi'ni teftiș etmiștir. Bu teftişin neticesinde oluşan rapor, Kırkkilise Mutasarrıflığı'na verilmiştir. Kırkkilise Mutasarrıflığ bu raporu incelemiş ve bu incelemenin sonucunda oluşan cevap niteliğindeki rapor sadece bir gün sonra 3 Nisan 1917'de Hapishaneler ve Tevkifhaneler Müfettiş:i Umumi Canibi Ali'sine yani Dr. Pollitz'e verilmiştir. Dr. Pollitz'in sorularına ve tespitlerine verilen cevaplardan oluşan bu rapor I. Dünya Savaşı'nın sonlarına doğru Kırkkilise Hapishanesi'nin durumunu büyük ölçüde ortaya koymaktadır. Adı geçen rapora göre mahkûmlar hakkında tatbik edilen ıslah cezalarından olan hücreye konulma sadece bir kişiye uygulanmıştır. Bu şahıs yirmi gün boyunca hücrede kalmıştır. Bu mahkûmun hücreye konulmasına sebep olan olay ise bundan bir sene önce gerçekleşmiş ve şu şekilde gelişmiştir: On beş seneye mahkûm olan bir şahıs bir gece diğer mahkûmlar uykuda iken cinnet geçirmiştir. Uykuda bulunan diğer mahkûmların başlarına eline geçirebildiği sert cisimler ile vurmuştur" (Demirkol, 2012:156).

Bu bilgilerden hareketle özgün durumunda da hapishanede hücrelerin var olduğu anlaşılmaktadır. Tavanlarının betonarme ile sıvanmış olması zaman içinde yapılan tamiratları göstermektedir.

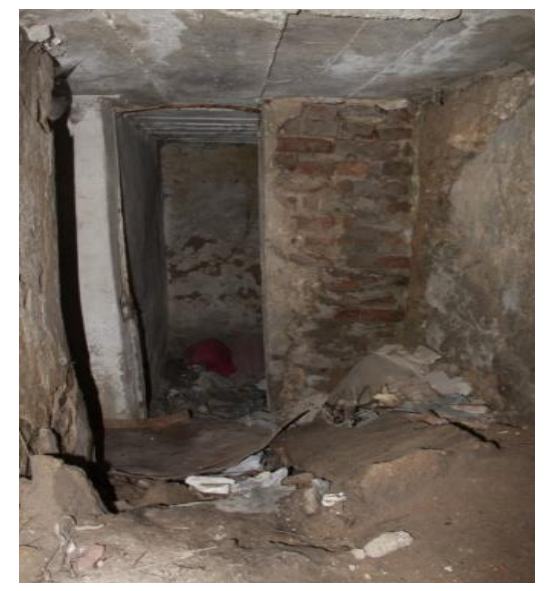

Resim 5: Bodrum kat hücre

Yapının zemin katı merdiven holü, üç adet oda, ziyaretçi holü, görüş kabini, ikinci hol, iki adet koğuş, üçüncü hol ve tekrar bir koğuştan ibarettir.

Yapının girişini sağlayan demir ferforje kapının açıldığı alan, doğu yönündeki odaya ve ziyaretçi holüne geçişi sağlamaktadır (Resim 6-7). Birinci kata ulaşım için kullanılan iç merdivenler de bu bölümde yer 
almaktadır. Batı cepheye bakan sahanlıkta bir adet ahşap kapı boşluğu bulunmaktadır. Tavanı ahşap olarak yapılmışırı ancak günümüzde tamamen yıkılmıştır.

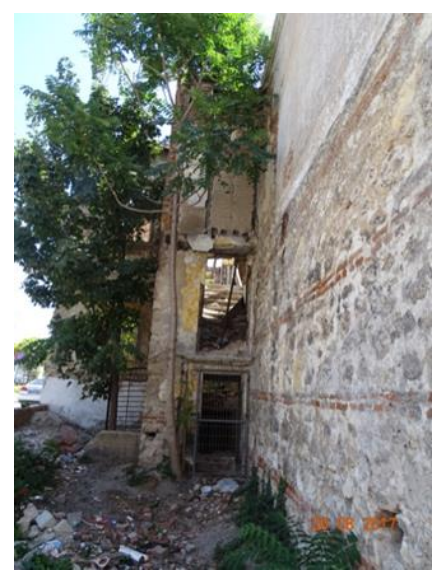

Resim 6: Merdiven holüne açılan yan kapı

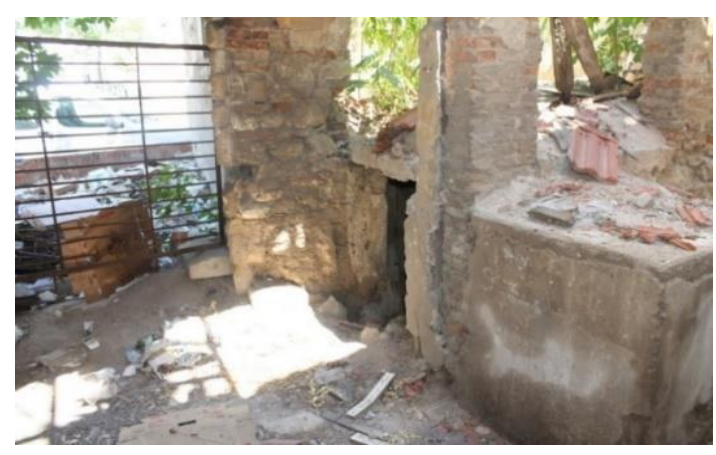

Resim 7: Zemin kat Merdiven Holü

Merdiven holünden ulaşılan oda kuzey ve batı cepheye bakan ahşap kanatlı birer pencere ile aydınlanmaktadır. Hücrelerin yer aldığı bodrum kat bu odanın altına tekabül etmektedir. Odanın tavanı tamamen yıkılmıştır.

Merdiven holünden ulaşılan ikinci oda kuzeye bakan iki adet, güneye bakan bir adet olmak üzere ahşap çerçeveli, demir parmaklıklı, basık kemerli 
toplam üç pencere ile aydınlanmaktadır ${ }^{11}$. Pencere boşlukları dıştan içe doğru genişletilerek mekânın daha aydınlık olması sağlanmıştır. Odaya geçişi sağlayan girişte günümüzde kapı kanatları mevcut değildir. Zemin döşemesi şap beton olan alanda duvarlarda sıva üzeri boya uygulanmıştır. Tavan kaplamasının çökmesi sonucu ahşap kirişler ve üst kat döşeme kaplaması görülmektedir (Resim 8).

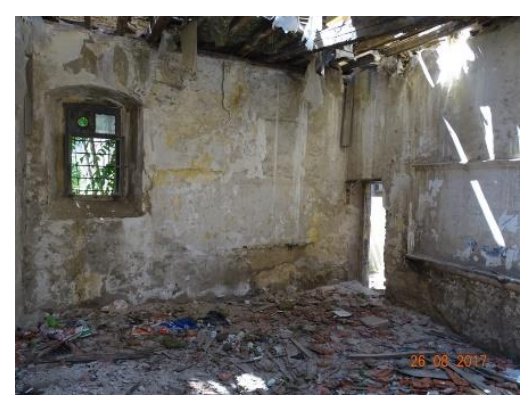

Resim 8: İkinci Oda

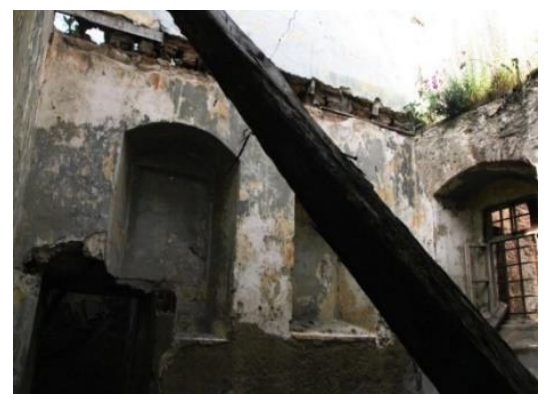

Resim 9: Üçüncü Oda

Merdiven Holünden üçüncü bir odaya daha ulaşılmaktadır. Odanın tavanı tamamen çökmüştür. Odaya girildiğinde sol duvarda iki adet niş ve doğu yönünde iki adet pencere görülmektedir (Resim 9-10).

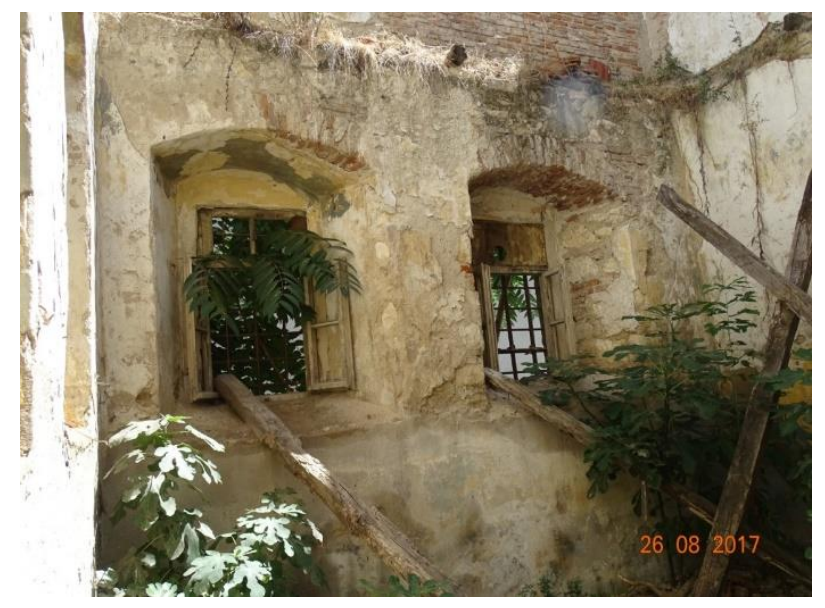

Resim 10: Üçüncü Oda, pencereler

\footnotetext{
${ }^{11}$ Özgün pencerelerin hepsi aynı özellikte olduğu için, diğer odaların tanımlamaları yapılırken bilgi tekrarına kaçmamak adına pencerelerin biçimsel özelliklerine değinilmeyecektir.
} 
Merdiven holünden demir bir kapı ile mahkûmların ziyaretçileriyle görüşleri için kullanılan ziyaretçi holüne geçilmektedir. Görüş kabini tel örgü ile sınırlandırılmıştır. Bu duvarın üst kısmında üç adet ahşap kanatlı pencere bulunmaktadır. Tavandaki ahşap kirişler sağlam durumdadır, döşemesi ise şap kaplamadır (Resim 11).

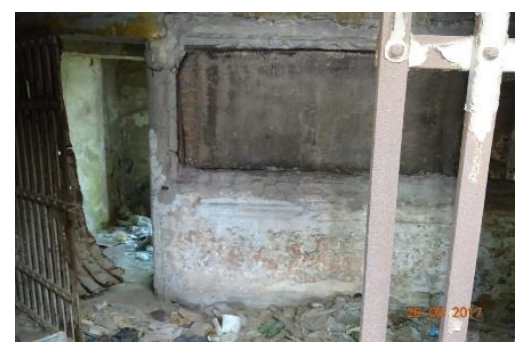

Resim 11: Ziyaretçi Holü

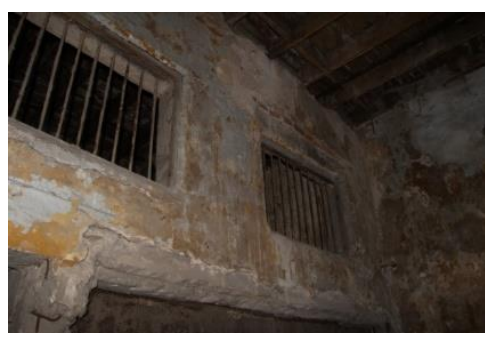

Resim 12: Ziyaretçi Holü pencereler

Ziyaretçi holünden ziyaretçi odasına giriş sağlanmaktadır. Ziyaretçiler ile mahkûmların görüşmesi için düzenlenmiştir ve duvarda bulunan pencere, tel örgü ile kapatılmıştır. Duvarın üst kısmında üç adet demir parmaklıklı pencere bulunmaktadır (Resim 12). Zemin kaplaması şap, duvarlar sıva üzeri boyadır. Tavanlar ahşap kiriş ile geçilmiştir.

Görüş kabininin güney yönünde hol devam etmektedir ve aynı zamanda batı yönünde yer alan koğuşa geçişi sağlamaktadır (Resim 13). Arka cepheden bir giriş kapısı bulunmaktadır. Arka cepheye açılan kapı boşluğu üst kata çıkan muhdes betonarme merdivenin altına denk gelmektedir. Zemin kaplaması şap, duvarlar sıva üzeri boyadır. Tavanlar ahşap kiriş ile geçilmiştir.

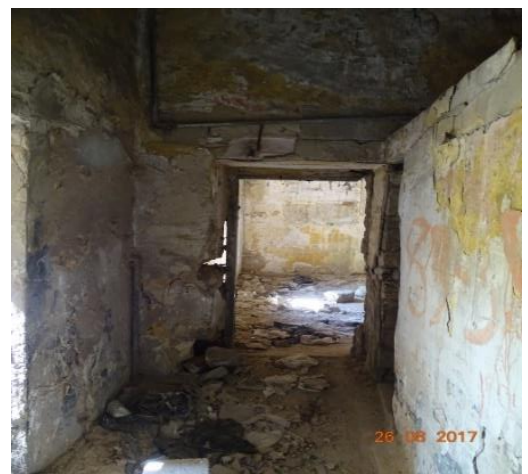

Resim 13: Hol'den bat1 yönünde yer alan koğuşa geçilen giriş 
Holden doğu yönünde bir koğuşa geçilmektedir (Resim 14). Kapıdan odaya girildiğinde sol duvarda bir adet, doğu duvarda ise sonradan kapatılmış üç adet pencere bulunmaktadır (Resim 15). Odanın tavanı betonarme döşeme olup, zemin moloz ile kaplıdır.

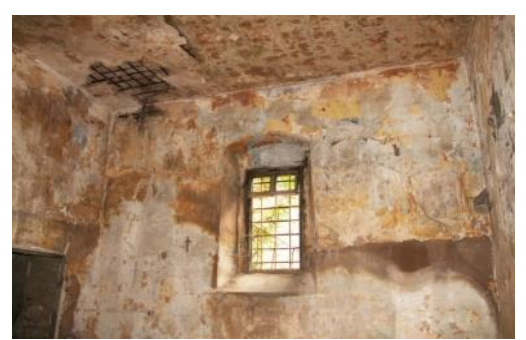

Resim 14: Doğu yönünde yer alan koğuş

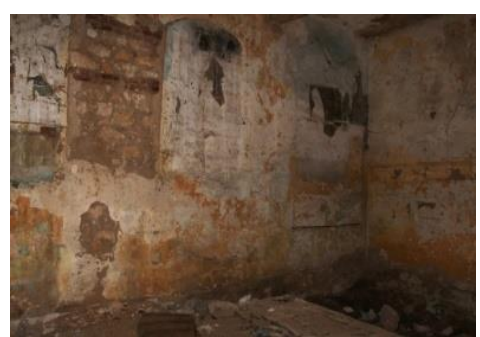

Resim 15: Kapatılmış pencereler

Ziyaretçi kabininin arkasındaki holden yapıya sonradan eklenen uzunca bir koridora geçilmektedir. İki adet betonarme kolon ve tuğla duvarla kapatılmıştır. Bahçeye bakan duvarda briket ile kapatılmış olan bir kapı boşluğu yer almaktadır. Döşemesi şap olup tavan ise sıva üzeri boyadır (Resim 16).

Koridordan büyük bir odaya geçilmektedir. Doğu yönünde üç, koridora bakan iki pencere ile aydınlık bir ortamdır. Döşeme kaplaması dökme mozaik, tavan ise sıva üzeri boyalıdır (Resim 17).

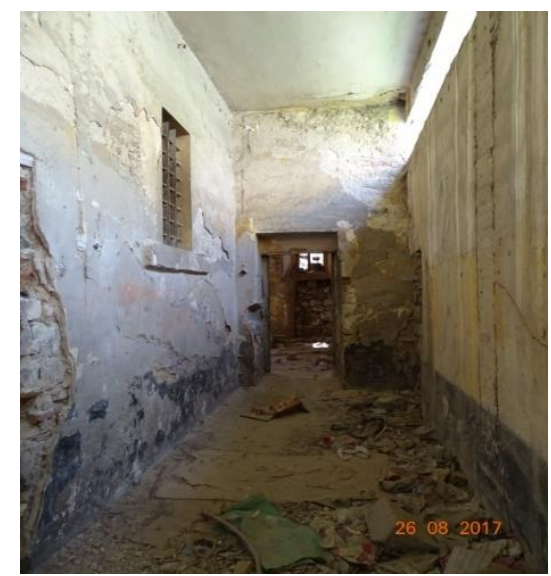

Resim 16: Koridor 


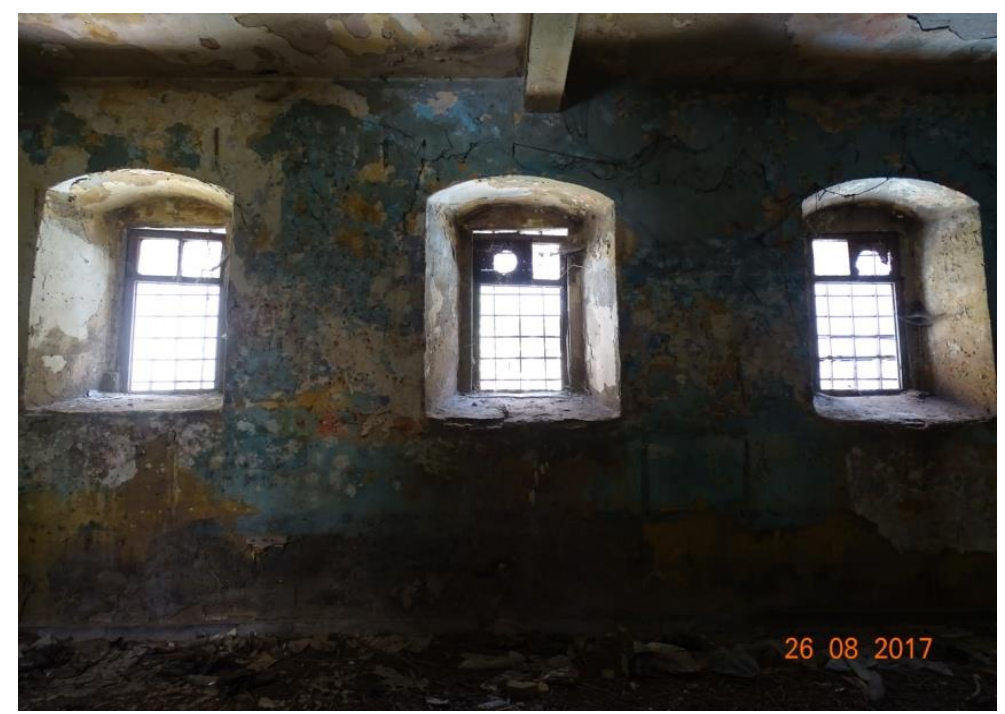

Resim 17: Doğu yönündeki koğuş

Koridorun güneyinde bir koğuş daha yer almaktadır. Güneye bakan üç adet doğuya bakan iki adet pencere ile aydınlanmaktadır. Döşemesi şap olup tavan ise sıva üzeri boyadır (Resim 18).

Yapının 1. katı koridor, 2 koğuş, 3 oda, merdiven holü, hole açılan 2 oda, 1 koğuş, lavabo ve wc ayrıca nöbetçi odasından oluşmaktadır.

Yapının sağ cephesinde yer alan betonarme merdiven ile bu kata ulaşıldıktan sonra demir kapı ile üst katta yer alan koridora giriş sağlanmaktadır. Üst katta yer alan koğuşlara ulaşım bu koridordan yapılmaktadır (Resim 19). Batı cepheye bakan üç adet pencere ile aydınlanmaktadır. Zemin kaplaması şap olan bölümde tavan ve duvarlarda sıva üzeri boya uygulanmıştır. Dökülen boyalardan tuğla duvarlar belli olmaktadır. Koridorun kuzey yönünde nöbetçi odası bulunmaktadır (Resim 20). 


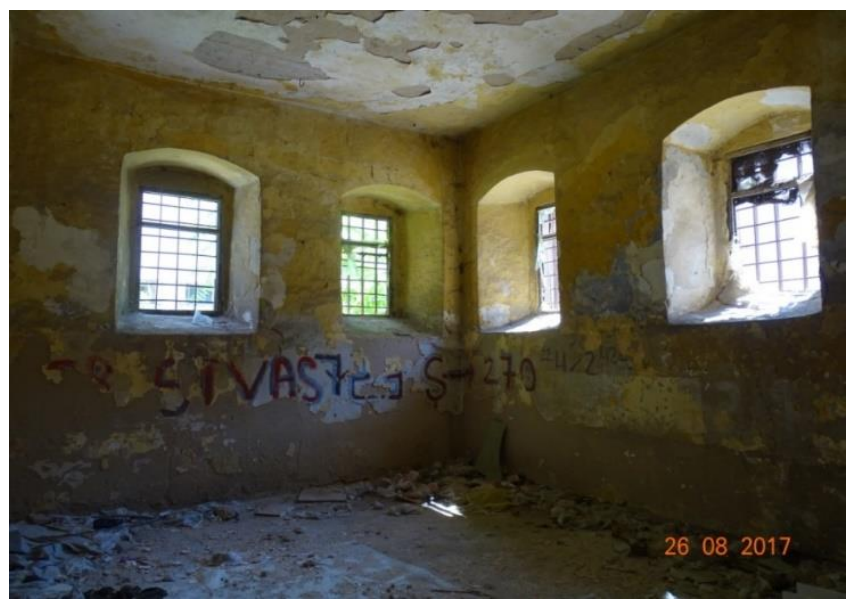

Resim 18: Güney Koğuş

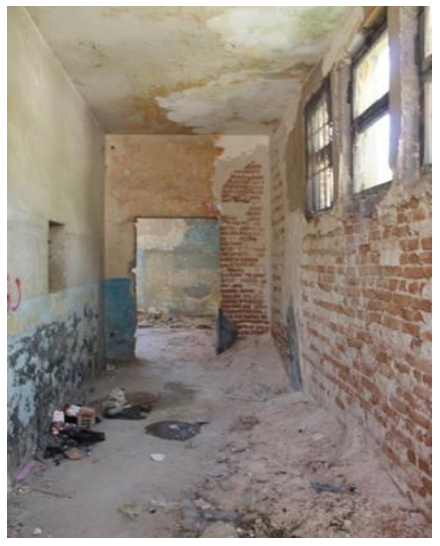

Resim 19: Üst kat koridoru

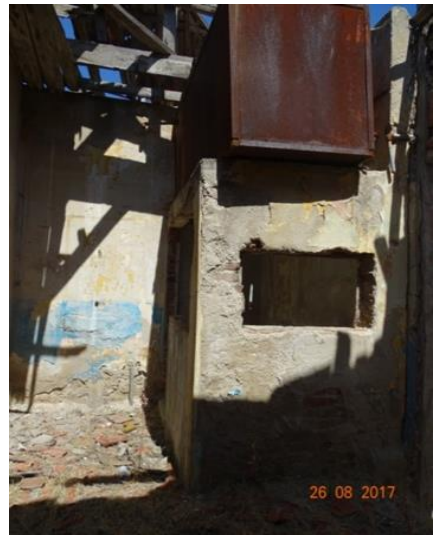

Resim 20: Nöbetçi Odas1

Koridorun güney yönünde, güney ve doğu duvarında yer alan üçer pencere ile aydınlanan bir koğuş yer almaktadır. Pencere açıklıkları tavana çok yakın mesafededir. Ahşap çerçeveli, demir parmaklıklı bu pencereler zemin kat pencerelerinden form ve ölçek açısından farklılıklar göstermektedirler (Resim 21-22). Zemin kaplaması şap olup, tavan ve duvarlarda sıva üzeri boya uygulanmıştır. Kapı açıklığından girildiğinde sağda kalan duvar üzerindeki boya ve sıvanın büyük bölümünün dökülmesi sonucu tuğla duvar ortaya çıkmıştır. 


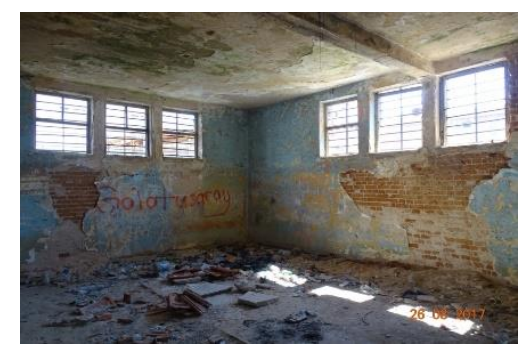

Resim 21: Güney Koğuş

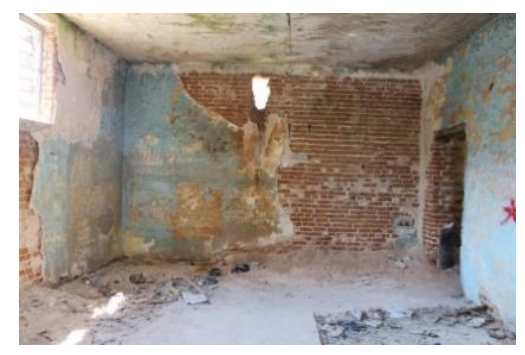

Resim 22: Güney Koğuş

Koridorun kuzey ucundan, doğu yönünde yer alan geniş bir koğuşa geçilir. Doğuya bakan altı adet ve koridora bakan iki adet pencere ile aydınlanmaktadır. Pencereler güney yönündeki oda pencereleri ile aynı niteliktedir (Resim 23-24).

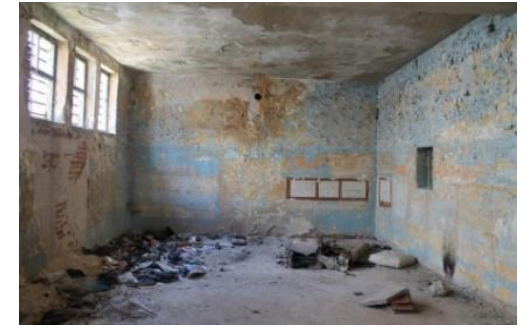

Resim 23: Doğu Koğuş

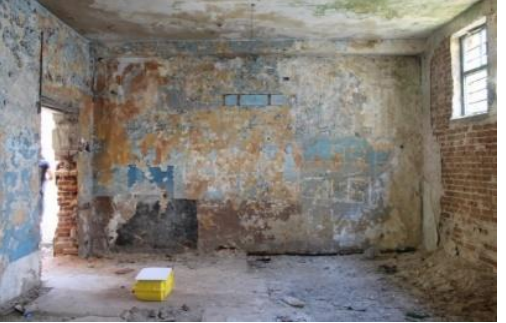

Resim 24: Doğu Koğuş

Koridorun kuzeyinde yer alan nöbetçi odasının hemen doğusunda bir oda daha bulunmaktadır. Doğuya bakan dikdörtgen formlu, ahşap çerçeveli ve demir kafesli iki adet pencere ile aydınlanmaktadır. Bu bölüm üzerindeki çatı örtüsü ve tavan yıkılmıştır. Duvarlara uygulanan sıva ve boyanın büyük kısmı dökülmüş̧ür. Zemin döşemesi yıkıldığı için alt katta yer alan oda görülmektedir (Resim 25-26).

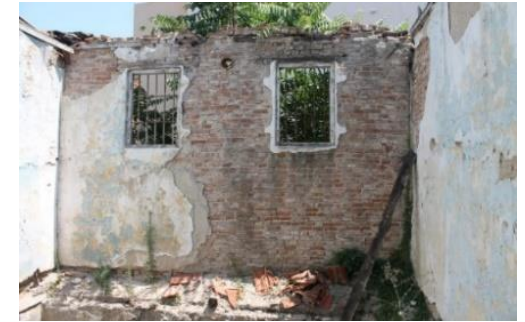

Resim 25: Doğu yönündeki diğer oda

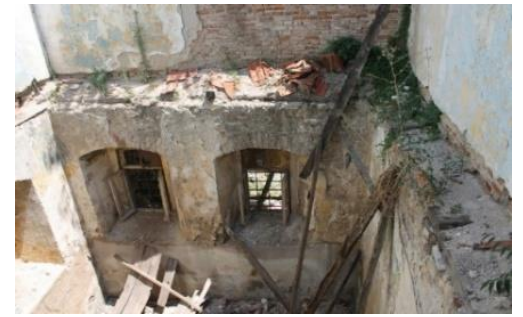

Resim 26: Odadan zemindeki odaya bakış 
1. kat döşemesinin büyük bir kısmının yıkılmış olmasından dolayı kuzeyde yer alan odalara girilememiştir. Bu bölümün döşemesi ahşap taşıyıcı sistemde olup, çatısı tamamen yıkılmıştır (Resim 27). Pencerelerinin ahşap olduğu ve kanatlarının yok olduğu görülmektedir. Pencere dışlarında demir parmaklıklar bulunmaktadır.

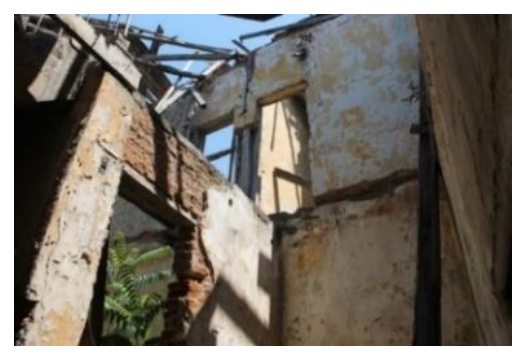

Resim 27: Kuzeyde yer alan odalar

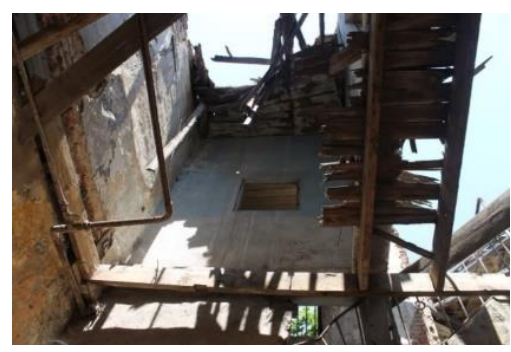

Resim 29: Yıkılan oda, içten görünüş

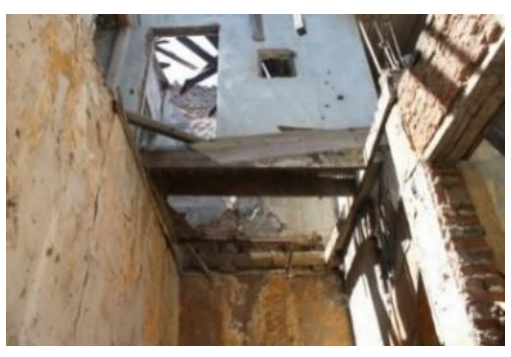

Resim 28: Merdiven Holü

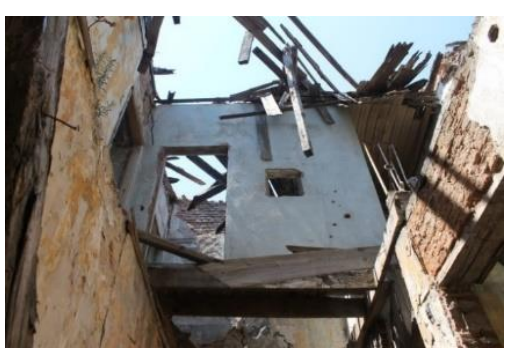

Resim 30: Yıkılan oda, dıştan görünüş

Bu iki oda arasındaki duvar bağdadi tekniğinde yapılmıştır. Günümüzde merdiven holü harap durumdadır. Merdiven Holünün üç adet ahşap penceresi bulunmaktadır (Resim 28). Merdiven holü ile batı yönünde yer alan büyük odanın arasında kalan daha küçük ölçekli iki oda daha bulunmaktadır (Resim 29-30).

Koridordan girişin sağlandığ 1 batı koğuşunun kapısı mevcut değildir. Ancak ahşap kapı sövesinin parçaları günümüze ulaşmıştır. Odanın güney duvarında bir, batı yönünde altı adet olmak üzere toplam yedi pencere ile aydınlanmaktadır. Pencereler demir parmaklıdır (Resim 31). Tavan döşemesi ve çatı yıkılmıştır. Batı koğuşunun girişinin hemen sağında bir oda bulunmaktadır. Koğuşun önünde yer alan hole bakan demir kapaklı küçük bir penceresi bulunmaktadır. Nöbetçi odasının kuzeyine iki adet wc yerleştirilmişsir. 


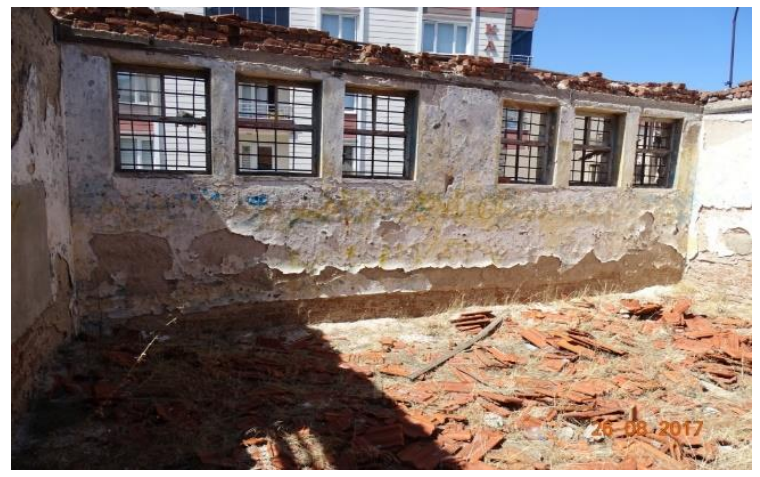

Resim 31: Batı koğuşu

Kuzeye bakan ön cephede iki kat arasında taş silme, köşelerde ve pencere aralarında yer alan plasterler hareketliliği sağlayan, ana cepheyi vurgulayan unsurlardır. Kuzey cephede iki oda çıkma yapmakta, merdiven holü ve batıda yer alan oda ile cephe içe doğru kademelenmektedir. Zemin kat pencere kenarlarında taş söve, 1. katta ise tuğla söve kullanılmıştır.

Yapının diğer cephelerinde aynı özen görülmez. Sıvalar büyük oranda dökülmüştür. Çatının kalan bölümlerinden kırma çatı, örtü malzemesinin ise marsilya kiremidi olduğu anlaşılmaktadır (Resim 32). Güney cephede pencerelerin aşağı kısımlarında yer alan bazı taşlar üzerine isimler kazınmıştır (Resim 33). Avluda gezinen mahkûmların yazmış olma ihtimali yüksektir. Bunlardan birinde yer alan "Mustafa Yıldırım 1930 Çankırı" yazısı okunabilmektedir.

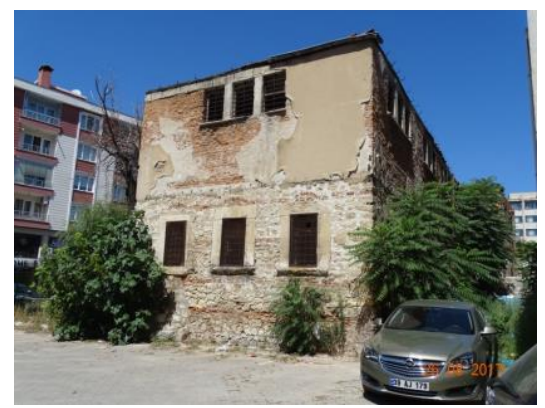

Resim 32: Güney cephe

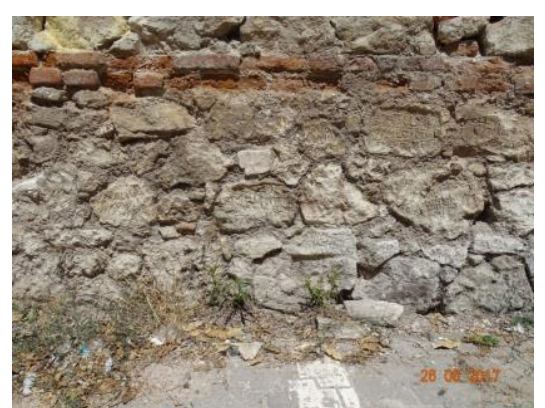

Resim 33: Güney cephede yer alan yazılar 
Yapının batı cephesinde, kuzeybatı köşede yer alan mekân oda genişliğinde dışa taşar (Resim 34-35). Bu mekânların güney duvarına bitişik merdivenle sonradan ilave olduğu düşünülen ve güneye doğru uzanan mekânlara ulaşılır.

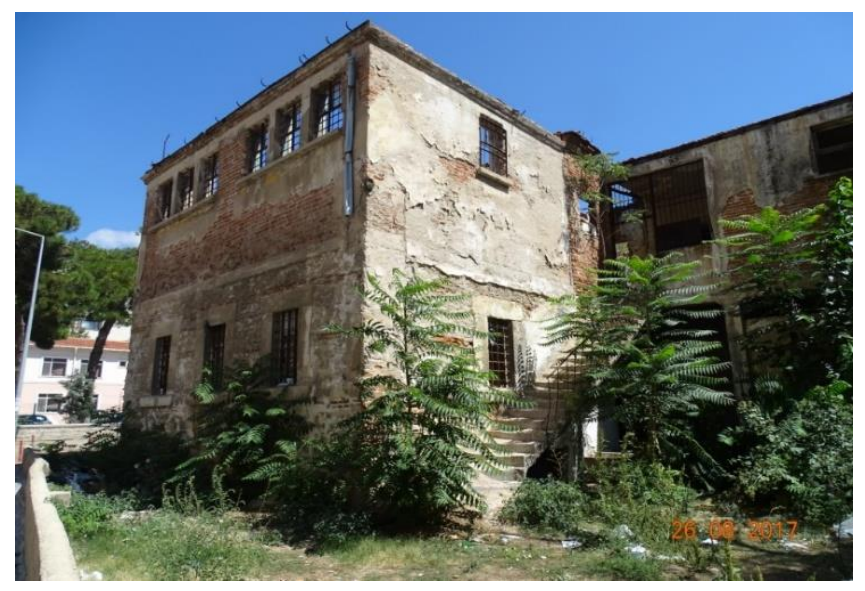

Resim 34: Batı cephesi, köşe

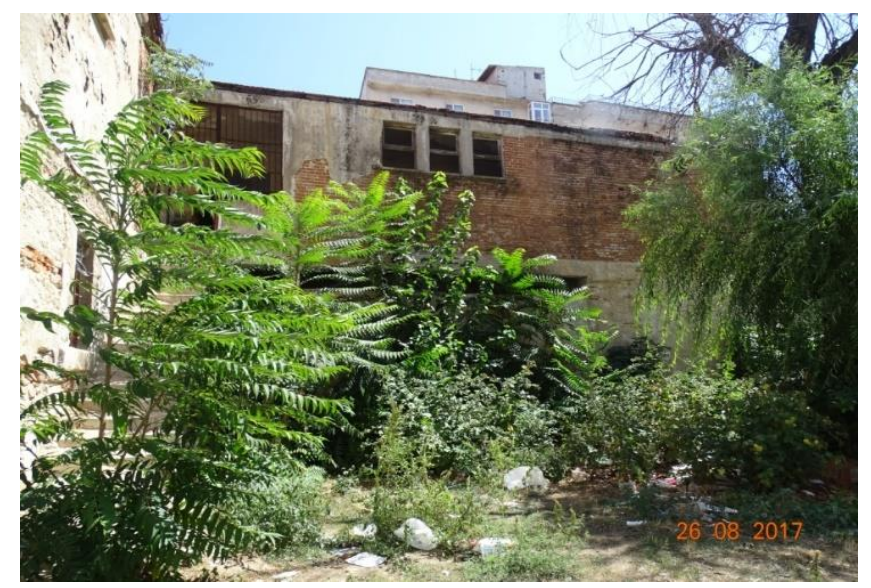

Resim 35: Bat1 cephe

\section{Değerlendirme ve Sonuç}

Kirklareli Hapishanesi kat silmesi, ana cephede yer alan plasterlerle hareketlendirilen ana cephesi ile 19. yy özelliği taşımaktadır. Aynı dönemde 
Kırklareli'nde inşa edilen kamu ve sivil mimarlık örnekleriyle, cephe özellikleri, malzeme ve teknik açısından ortak özellikler sergilemektedir.

Plan içerisinde birkaç koridor ve bu koridorlara açılan mekânlardan oluşan Kırklareli Hapishanesi, daha düzgün ancak hole açılan mekânlar açısından benzer şemada ve yakın yıllarda inşa edilen Gümülcine Hapishanesi (Demirkol, 2012:53) ile benzerlik taşımaktadır (Belge 1). Gümülcine Hapishanesi de Hükümet Konağının bulunduğu yerde inşa edilmiştir.

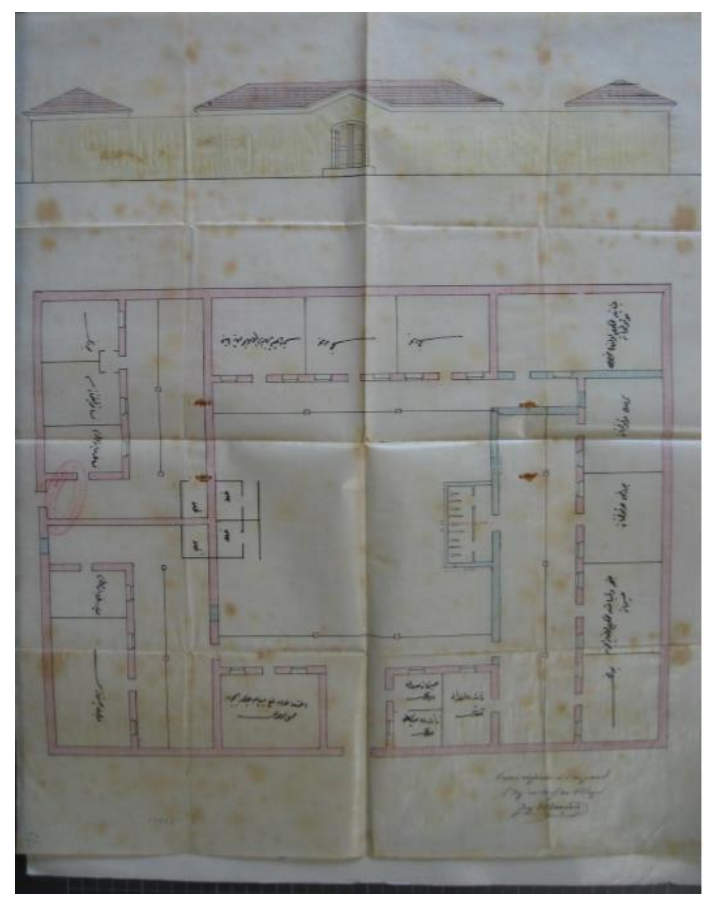

Belge 1: Gümülcine Hapishanesi (Kurtuluş Demirkol'dan)

Kütahya Hapishanesinin mimarisi hakkında; "hapishanenin küçük orta avlulu ve bir kısmının iki katlı, bir kısmının ise tek katlı olduğu; bu yapının yanındaki bölümün, dikdörtgen taşkın söveli pencereler, geniş ve dalgalı taş silmeler, köşelerde, araları derzlenmiş köşe plasterlerinin olduğu, kat aralarının ahşap olabileceği” kaynaklarda belirtilmektedir (Bozkurt, 2012:263). Bu özellikleri Kırklareli Hapishanesi ile benzeşmektedir.

Osmanlı Döneminde, yeni yapılacak hapishanelerin sağlık koşullarına uygun modern bir şekilde inşa edilmesi amaciyla yeni yapılacak 
hapishanelerde gündüz imalathanelerde çalışan mahkûmların, gece hücrelerinde yatmaları yerine maddi manevi yorgunlukların azaltılması için düzenlenmiş olan bahçe ve gezinti yerlerinde belli bir süre hava almalarına izin verilmesi gündeme getirilmiştir. Sağlık ve ahlak mahkûmlar için önemli sayılmış ve bu nedenle hapishanelerin memleketin havadar bir yerinde bahçe ve gezinti yerlerin düzenlenebilec eği uygun arazilerde yapılması belirtilmiştir. Gönderilecek resim ve evrak keşfiyle birlikte arsa haritasının yollanılmasına dikkat çekilmiştir. Bunu takip eden süreçte de vilayet, liva ve kaza hapishanelerinin ıslahı hakkında plan, rapor ve keşifnamelerin hazırlanıp adliye nezaretine gönderilmesi istenmiştir. Buna uygun olarak da hazırlanan taslak aşağıdaki gibi düzenlenmiştir (Belge 2) (Tekin vd., 2008: 195:196).

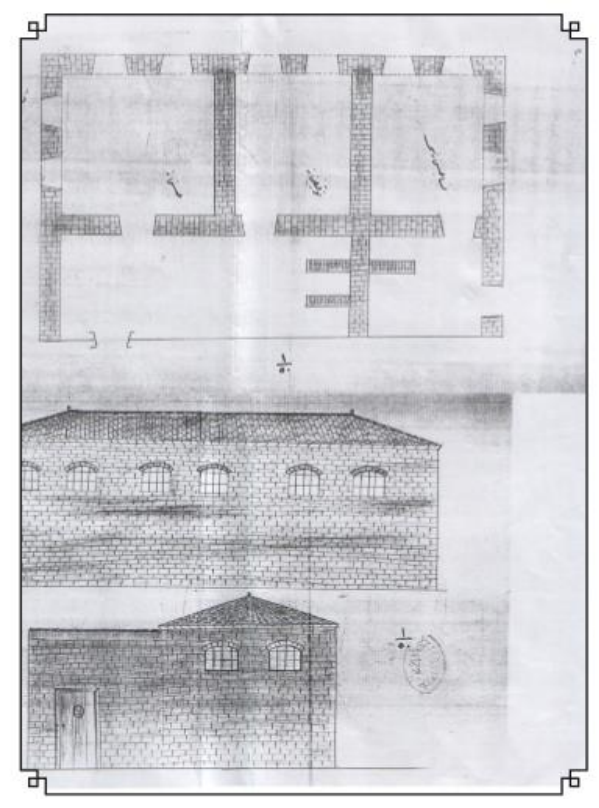

Belge 2: (Saadet Tekin'den)

Belge 2'de görüldüğü gibi Kırklareli Hapishanesi'nin güney bölümü hemen hemen bu plan şemasıyla örtüşmektedir. Doğrudan kaynak gösterilmeksizin ve herhangi bir kitabe olmamasına rağmen bazı gazetelerde ve internet sitelerinde yer alan (https://hyetert.org/2014/01/01/kirklareli:eski: hapishane:yeniden:ihalede/, erişim tarihi: 20.08.2020; https://www. pomakajans. com/kirklareli:eski:hapishane:yeniden:ihalede/57/, erişim tarihi: 20.08.2020); 
"1884 yılında Rum, Ermeni ahalinin ibadetlerini rahatça yerine getirilebilmeleri için Ay Andonis adına yapılmış kilisedir. Bu kiliseyi o yıllarda Ermeni vatandaşlarımız da kullanıyor olmalı. Mübadeleden sonra, cemaati kalmadığı için boşaltılarak, uzun yıllar cezaevi olarak kullanılmıştır".

şeklindeki ibarelerin arşiv belgelerinden ve yapılan bilimsel çalışmalardan hareketle yanlış ve yanlı bilgiler olduğu anlaşılmaktadır. Ayrıca yapının plan şeması kilise mimarisiyle hiçbir şekilde uyuşmamaktadır.

1867 yılında inşaatına başlanan Kırklareli Hapishanesi, 1888 yılında ihtiyaca cevap veremez hale gelince, Hapishane Binas1 etrafinda yer alan Jandarma Dairesi ve günümüze ulaşamayan Hükümet Konağıyla birlikte 1892 yılında yeniden inşa edilmiştir.

$\mathrm{Bu}$ bilgiler dikkate alındığında da Kırklareli Hapishanesinin doğrudan hapishane binası olarak tasarlandığı ve inşa edildiği anlaşılmakta (Şekil 2-4), Ermeni kilisesinin hapishaneye dönüştüğü bilgisinin yanlışlığı ortaya çıkmaktadır.

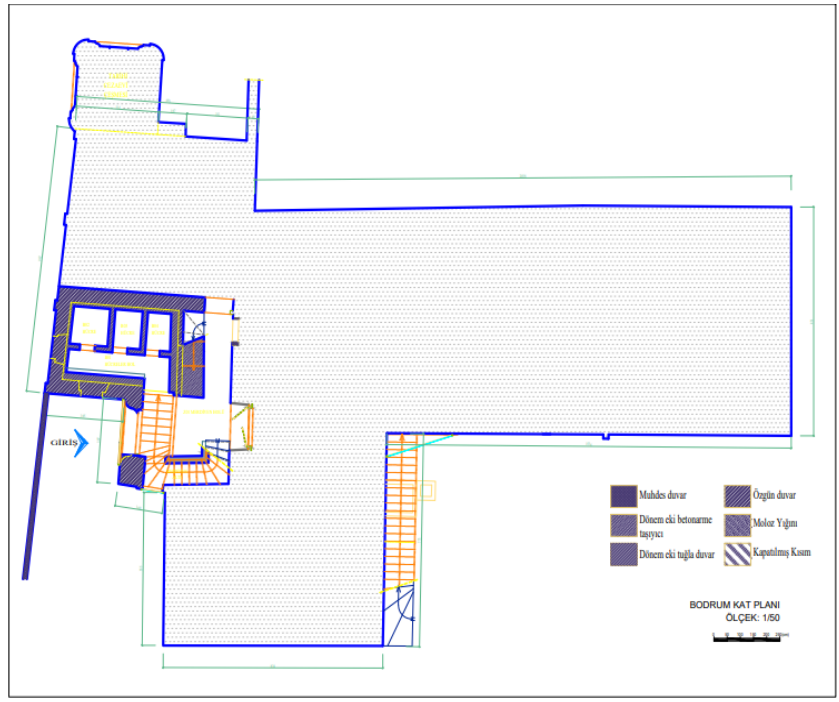

Şekil 2: Bodrum Kat Planı 


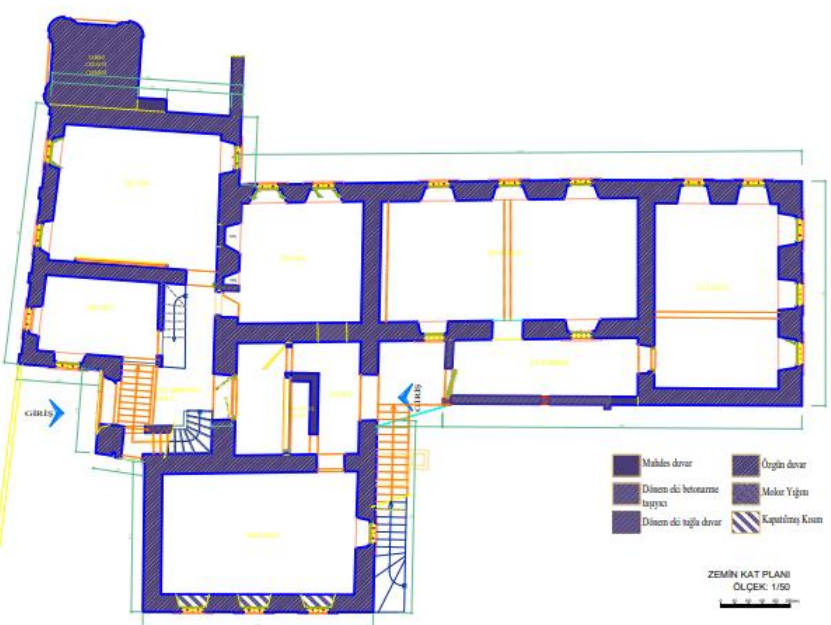

Şekil 3: Zemin Kat Planı

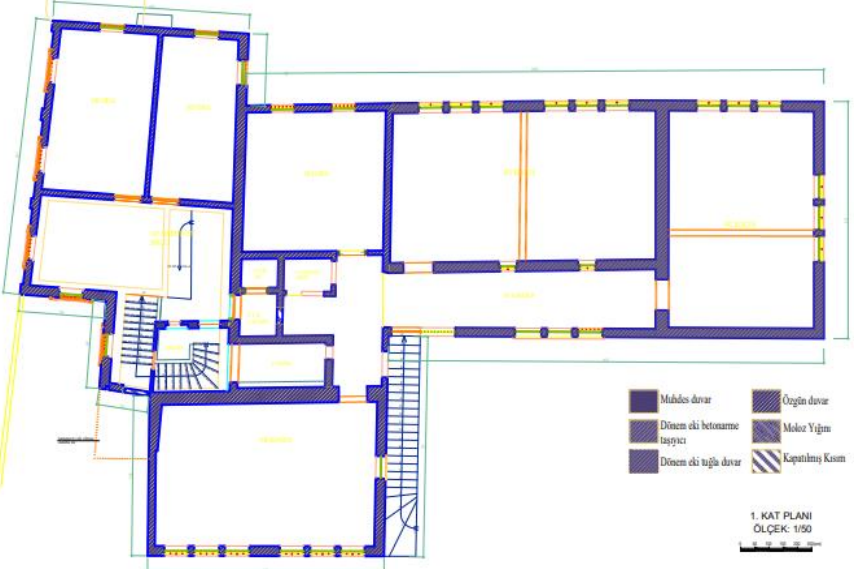

Şekil 4: 1. Kat Planı 
KAYNAKÇA

\section{Arşiv Belgeleri}

Devlet Arşivleri Başkanlığı Osmanlı Arşivi (BOA). DH.MKT. 1506/115

Devlet Arşivleri Başkanlığı Osmanlı Arşivi (BOA.) DH.MKT. 1562/36

Devlet Arşivleri Başkanlığı Osmanlı Arşivi (BOA.) DH.MKT. 1579/89

Devlet Arşivleri Başkanlığı Osmanlı Arşivi (BOA.) DH.MKT. 1737/56

Devlet Arşivleri Başkanlığı Osmanlı Arşivi (BOA.) DH.MKT. 1875/35

Devlet Arşivleri Başkanlığı Osmanlı Arşivi (BOA.) DH.TMIK.S 67/63

Devlet Arşivleri Başkanlığı Osmanlı Arşivi (BOA.) Y.A.RES. 151/61

Devlet Arşivleri Başkanlığı Osmanlı Arşivi (BOA.) DH.TMIK.S. 19/4

\section{Kitap ve Makaleler}

ADAK, Ufuk (2006), XIX. Yüzyılın Sonları XX. Yüzyılın Başlarında Aydın Vilayeti'ndeki Hapishaneler, Yüksek Lisans Tezi, Ege Üniversitesi Sosyal Bilimler Enstitüsü, İzmir.

AKBEY, Nazmiye (2015), XIX. Yüzyılın Sonları XX. Yüzyılın Başlarında Sinop Hapishanesi, Yüksek Lisans Tezi, Celal Bayar Üniversitesi Sosyal Bilimler Enstitüsü, Manisa.

AKBULUT, İlhan (2003), "İslam Hukukunda Suç ve Cezalar”, Ankara Üniversitesi Hukuk Fakültesi Dergisi, 52.1, 167-181.

AKIN, Hatice (2011), “Osmanlı Devleti’nde Hapishane Islahatına Dair 1893 Tarihli Bir Nizamname Önerisi”, History Studies, 3.3, 23-36.

AKPINAR, Özlem (2017), Meşrutiyetten Cumhuriyete Konya Hapishaneleri (18761922), Yüksek Lisans Tezi, Selçuk Üniversitesi Sosyal Bilimler Enstitüsü, Konya.

AKYÜZ ORAT, Jülide (2011), "Hapishane Islahatı Bağlamında Çerkes Hapishanesinin Modernleşme Çalışmaları”, Folklor/Edebiyat, 17.66, 8194.

AKYÜZ ORAT, Jülide, ÇELIK, Fadimana (2011), "Diyarbakır Vilayeti Hapishaneleri”, Sosyal Bilimler Enstitüsü Dergisi, 7, 73-95.

ARTUK, Mehmet Emin, ALŞAHIN Mehmet Emin (2015), "Hapis Cezalarının ve Cezaevlerinin Tarihi Gelişimi", Marmara Üniversitesi Hukuk Araştırmaları Dergisi Özel Sayı Mehmet Akif Aydın'a Armağan, 145-185. 
ATA, Ferudun (2016), “Osmanlı Dönemi’nde Bozkır Hapishanesi”, Uluslararası Sempozyum: Geçmişten Günümüze Bozkır, 393-398.

ATAR, Zafer (2011), “20. Yüzyıl Başlarında Turgutlu Hapishanesinin Genel Durumu", Celal Bayar Üniversitesi Sosyal Bilimler Dergisi, 9.1, 87-102.

AVCI, Mustafa (2004), Osmanlı Hukukunda Suçlar ve Cezalar, Bilimevi Basım, İstanbul.

AYDIN, Mehmet Akif (1997), “Osmanlı Ceza Hukuku”, Türkiye Diyanet Vakf İslam Ansiklopedisi, C: VII, 478-482.

AYDIN, Remzi (2018), "Mühendis Mehmed Ali Bey'in Avanos'taki Projeleri”, Istem, 16.32, 357 - 383.

AYDIN, Remzi (2019), "Mimar Kemaleddin Bey'in Hapishane Projeleri”, Osmanlı Sanatında Değişim ve Dönüşüm, 11-36.

AYDIN, Remzi (2020), “Alman Mimar August Carl Friedrich Jasmund'un Yedikule'deki Hapishane Projesi”, Türk: İslâm Medeniyeti Akademik Araştırmalar Dergisi, 15.29, 9-28.

BARDAKOĞLU, Ali (1997), “Ceza”, Türkiye Diyanet Vakfi Íslam Ansiklopedisi, C:VII, 470-478.

BARDAKOĞLU, Ali (1997), "Hapis”, Türkiye Diyanet Vakfi İslam Ansiklopedisi, Cilt:16, İstanbul.

BOZKURT, Nurgül (2012), “XX. Yüzyıl Başlarında Kütahya Hapishanesinin Genel Durumu”, Uluslararası Sosyal Araştırmalar Dergisi, 5.21, 261-277.

ÇAKMAKOĞLU KURU, Alev (2004), Sinop Hapishanesi, Atatürk Kültür Merkezi Başkanlığı Yayınları, Ankara.

ÇIÇEN, Ahmet (2010), II. Meşrutiyet Dönemi Cezaevi Islahatı, Yüksek Lisans Tezi, Afyon Kocatepe Üniversitesi Sosyal Bilimler Enstitüsü, Afyon.

DAŞCIOĞLU, Kemal (2010), “Osmanlı Arşiv Belgelerine Göre Bodrum Kalesi ve Hapishanesi”, Süleyman Demirel Üniversitesi Fen Edebiyat Fakültesi Sosyal Bilimler Dergisi, 212-225.

DEMİ, Emel (2013), Osmanl Devleti'nde Hapishane Reformu, Çanakkale Hapishanesi Örneği, Yüksek Lisans Tezi, Çanakkale Onsekiz Mart Üniversitesi Sosyal Bilimler Enstitüsü, Çanakkale.

DEMİRBAŞ, Timur (2010), "Hürriyeti Bağlayııı Cezaların ve Cezaevlerinin Evrimi”, Hapishane Kitabı, İstanbul, 28-34. 
DEMİRKOL, Kurtuluş (2012), II. Meşrutiyet Döneminde Edirne Vilayeti Hapishaneleri, Doktora Tezi, Sakarya Üniversitesi Sosyal Bilimler Enstitüsü, Sakarya.

DEMIRKOL, Kurtuluş (2014), “II. Meşrutiyet Döneminde İzmit Hapishanesi”, Uluslararası Gazi Akça Koca ve Kocaeli Tarihi Sempozyumu Bildirileri, Kocaeli.

DEMİKOL, Kurtuluş (2017), "Edirne Vilayeti Örneğinde Osmanlı Hapishanesi Çalışanları”, Balkan Araştırma Enstitüsü Dergisi, 6.1, 79-107.

DEMİRYÜREK, Halim (2016), "Hüdavendigar Vilayetinde Hapishaneler ve Mahpuslar (1914-1917)", Uluslararası Sosyal Araştırmalar Dergisi, 9.42, 552-562.

DEVELİĞLU, Ferit (1996), Osmanlıca: Türkçe Ansiklopedik Lügat, Ankara.

DURSUNKAYA, Ali Rıza (1948), Kırklareli Vilayetini Tarih, Coğrafya, Kültür ve Eski Eserleri Yönünden Tetkik, Birinci Cilt, Kırklareli.

FOUCOULT, Michel (1992), Hapishane’nin Doğuşu, Çev. Mehmet Ali Kılıçbay, Ankara.

GÖNÜLlÜ, Ali Rıza (2011). “Osmanlı Devleti'nin Son Döneminde Isparta Hapishanesi (1867-1920)", Selçuk Üniversitesi Türkiyat Araştırmaları Dergisi, 29, 342-392.

İLİŞ, Kibar (2019), II. Meşrutiyet Döneminde Bitlis Hapishaneleri, Yüksek Lisans Tezi, Bitlis Eren Üniversitesi Sosyal Bilimler Enstitüsü, Bitlis.

KARAKAYA, Beyza (2016), Musul Vilayeti Hapishaneleri (1864-1918), Yüksek Lisans Tezi, Marmara Üniversitesi Türkiyat Araştırmaları Enstitüsü Türk Tarihi Anabilim Dalı, İstanbul.

KOÇ, Mehmet (2017), Osmanlı Hukukunda Ta'zir Suç ve Cezaları, Doktora Tezi, NEÜ Sosyal Bilimler Enstitüsü, Konya.

ÖZTÜRK, Sevcan (2014), XIX. Yüzyll Osmanlı Ceza Sisteminde Dönüşüm: Zindandan Hapishaneye Geçiş, Yüksek Lisans Tezi, Adnan Menderes Üniversitesi Sosyal Bilimler Enstitüsü, Aydın.

PARLAKOĞLU, Gizem (2018), II. Abdülhamit Dönemi Hapishanelerinin Genel Özellikleri ve Uygulamalar,, Yüksek Lisans Tezi, Mardin Artuklu Üniversitesi Sosyal Bilimler Enstitüsü, Mardin.

RUDOLF, Peters (2005), Crime and Punishment in Islamic Law, Cambridge. 
SEZER, Selahaddin (2019), Tanzimat Sonrası Osmanlı Hapishane Mimarisi: Işınsal Planlı Örnekler, Yüksek Lisans Tezi, Çankaya Üniversitesi Fen Bilimleri Enstitüsü, Ankara.

SUNAY, Serap (2018), "Son Dönem Osmanlı Taşra Hapishanelerine Bir Örnek: Bolvadin Hapishanesi", Afyon Kocatepe Üniversitesi Sosyal Bilimler Dergisi, 20.1, 43-66.

SÜLEK, Yahya (2019), 19. Yüzyıl Sonu ve 20. Yüzyıl Başlarında Teke Sancağı'nda Hapishaneler, Yüksek Lisans Tezi, Akdeniz Üniversitesi Sosyal Bilimler Enstitüsü, Antalya.

ŞEN, Hasan (2007), Osmanlı'da Hapishane Mefhumu, Osmanlı'da Asayiş, Suç ve Ceza, Tarih Vakfı Yurt Yayınları, İstanbul.

ŞENTOP, Mustafa (2004), Tanzimat Dönemi Osmanlı Ceza Hukuku: Kanunlar, Tadiller, Layihalar, Uygulama, Yaylacık Matbaası, İstanbul.

ŞENYURT, Oya (2010), "Proje ve Belgeleriyle 20. Yüzyıl Başında İzmit Hapishanesinin Tasarımı", Mimarlk Tarihi, 352, 60-65.

ŞIMŞEK, Eyyub (2017), "XX. Yüzyıl Başlarında Trabzon Hapishanesi (1900-1914)”, Karadeniz Incelemeleri Dergisi, 23, 163-196.

TEKIN, Saadet (2006), "XX. Yüzyılın Başlarında Aydın Vilayeti ve Mülhakatındaki Hapishanelerin Genel Durumu", Celal Bayar Üniversitesi Sosyal Bilimler Dergisi, 4.2, 65-77.

TEKIN, Saadet, ÖZKES, Sevilay (2008), "Cumhuriyet Öncesi Türkiye'de Hapishane Sorunu", ÇTTAD, VII/16.17, 195-196.

TEMEL, Mehmet (2009), "XX. Yüzyılın Başlarında Menteşe Sancağı Hapishaneleri”, Selçuk Üniversitesi Türkiyat Araştırmaları Dergisi, 26, 109-135.

UYANIK, Mehmet Zeki (2017), İslam Hukukunda Hapis Cezasl ve Hapishane, Hikmetevi Yayınları, İstanbul.

YAŞAR, Ayşegül (2019), Osmanl Devleti'nin Son Dönemlerinde Antalya Hapishanesi, Yüksek Lisans Tezi, Kütahya Dumlupınar Üniversitesi Sosyal Bilimler Enstitüsü, Kütahya.

YILDIZTAŞ, Mümin (1997), Mütareke Döneminde Suç Unsurları ve İstanbul Hapishaneleri, Yüksek Lisans Tezi, İstanbul Üniversitesi Sosyal Bilimler Enstitüsü Türkiye Cumhuriyeti Tarihi Anabilim Dalı, İstanbul.

YILMAZ, Banu (2015), Osmanlı Dönemi Bursa Hapishanesi, Yüksek Lisans Tezi, Uşak Üniversitesi Sosyal Bilimler Enstitüsü, Uşak. 
KIRKLARELİ HAPISHANESI

YOLAÇAN, Seval (2019), Nevşehir Hapishanesi (1849-1920), Yüksek Lisans Tezi, Aksaray Üniversitesi Sosyal Bilimler Enstitüsü, Aksaray.

\section{Çevrimiçi Kaynaklar}

Sozluk.gov.tr, erişim tarihi: 21.07 .2020

https://hyetert.org/2014/01/01/kirklareli:eski:hapishane:yeniden:ihalede/

https://www.pomakajans.com/kirklareli:eski:hapishane:yeniden:ihalede/57/ 